\title{
Synodale machteloosheid en mystieke vrijzinnigheid: Louis A. Bähler (1867-1941) en de Gereformeerde Bond
}

\author{
H. van den Belt
}

\begin{abstract}
The publication of Buddhist mission: 'Christian' barbarism in Europe, translated by Louis Adriën Bähler (1867-1941), a Christian anarchist and pastor of the Dutch Reformed Church, led to the founding of the Reformed League in the Dutch Reformed Church (Nederlandse Hervormde Kerk). The classis censured Bähler, but Synod rehabilitated him and therefore the orthodox Reformed within the church charged that Synod's actions revealed its powerlessness to maintain doctrinal discipline. Bähler's Buddhist leanings have drawn much attention. This article places Bähler's sympathy for pietism and mysticism in the broader context of his theology, one characterized by a spiritualization and moralization of the Gospel.
\end{abstract}

In de universiteitsbibliotheek van Groningen bevindt zich een exemplaar van De vruchtbaarmakende wijnstok Christus van Johannes Teellinck (circa 16231673). Er staat een gedichtje in:

Bij den titel

Terwijl men mij met listig werk

Wil werpen uit de zichtb're kerk

Zal toch de aanslag nooit gelukken

Om mij van Christus af te rukken

Hij blijft mijn Wijnstok, ik Zijn rank

Draag ik slechts vrucht, Zijn kracht ten dank

$$
\text { Dr. Louis A. Bähler }
$$

(Op 21 Febr. 1905 toen ik in het bezit van dit boek kwam) ${ }^{1}$

1 Johannes Teellinck, Den vruchtbaermakenden wijnstock Christus, dat is een eenvoudige onderrichtinge aan alle ware Christenen, hoe dat sy sullen mogen volharden in den geloove: ende den Geest des Heeren Jesu so by haer hebben, ende houden: dat sy uyt Christo moghen deelachtigh worden, een geestelijcke kracht, om vruchtbaer te wesen in goede werken, Kampen 1666-1667, schutblad deel 1, exemplaar Bibliotheek Rijksuniversiteit Groningen. Het exemplaar van Bähler bevat verder geen aantekeningen. Het is als scan opgenomen in GoogleBooks: books.google.nl/books?id=40RhiDXtst4C\&dq. 
Dit gedicht is geschreven door de predikant die bekendstaat om zijn boeddhistische sympathieën en wiens rehabilitatie door de hervormde synode de aanleiding vormt voor de oprichting van de Gereformeerde Bond. Het werk van Teellinck spreekt hem zo aan dat hij er een bloemlezing uit publiceert. ${ }^{2}$ Waarom heeft deze vrijzinnige theoloog sympathie voor de geschriften van een predikant die tot de Nadere Reformatie wordt gerekend?3 $\mathrm{Na}$ een schets van de kerkelijke procedure en de beeldvorming over Bählers opvattingen in de kring van de Gereformeerde Bond, plaatst dit artikel Bählers voorliefde voor Teellinck in de context van zijn theologie. ${ }^{4}$

\section{Het predikantengeslacht Bähler}

Louis Adriën Bähler (1867-1941) volgt het voetspoor van zijn vaderen in de theologiestudie en het predikantschap. ${ }^{5}$ Wellicht schuilt in zijn opvoeding ook meteen een van de redenen voor zijn sympathie voor de piëtistische gereformeerde stroming. In ieder geval is hij er van huis uit mee vertrouwd. Louis' overgrootvader, Louis Henri Bähler (1765-1836), is vanuit Zwitserland naar Nederland gekomen en dient als predikant de Waalse kerk te Zwolle. ${ }^{6}$ De wortels van de familie liggen in het Reveil. Zijn grootvader, Christian Daniël Louis Bähler (1806-1857), richt zich in 1842 samen met Bernardus Moorrees (1780-1860), predikant in Wijk bij Heusden, tot de hervormde synode en koning Willem II met het verzoek om herstel van het gezag van de gerefor-

2 Johannes Teellinck, Louis A. Bähler (red.), De vruchtbaar makende wijnstok Christus [Geschriften over het ingekeerde leven, 3], Den Haag 1908. Er zijn weinig voetnoten, maar wel enkele correcties. Waar Teellinck Psalm 42 aan David toeschrijft, verandert Bähler David in 'de psalmist' en merkt in een voetnoot op: 'Er staat verkeerdelijk: David. B.' Teellinck, Bähler, Vruchtbaar makende wijnstok, 19.

3 Over Johannes Teellinck, zie onder andere P.J. Meertens, 'Johannes Teellinck' in BLGNP, 1:371-372 en T. Brienen, 'Johannes Teellinck (ca. 1623-1674)', in T. Brienen e.a., Figuren en thema's van de Nadere Reformatie, Kampen 1990, 2:46-56.

4 Ik dank Jan Koops en beide externe referenten voor hun kritische opmerkingen bij een eerdere versie van dit artikel.

5 Zie over Bähler, D. Jansen, 'Louis Adriën Bähler,' in: Biografisch Lexicon voor de Geschiedenis van het Nederlandse Protestantisme, Kampen 2001, 5:27-29 en S.J. Visser, 'Bähler, Louis Adriën (1867-1941)' in Biografisch Woordenboek van Nederland, resources.huygens.knaw. nl/bwn1880-2000/lemmata/bwn5/bahler, geraadpleegd op 29 november 2018.

6 De gegevens over het geslacht Bähler zijn ontleend aan Jan Koops, 'Een man van geestdrift en verontwaardiging: Louis Adriën Bähler', in Vrijzinnig verleden, deel 2, z.p. 2019, 3-31. 
meerde belijdenisgeschriften in de Nederlandse Hervormde Kerk. ${ }^{7}$ Zijn vader, Louis Henri Antoine Bähler (1838-1932), wordt in de pastorie van Oosterwolde geboren en wordt predikant, met Kesteren in de Betuwe als eerste standplaats. Daar ziet Louis Adriën het levenslicht.

Vier jaar later verhuist het gezin naar de geboorteplaats van vader Bähler, Oosterwolde in Gelderland, waar zijn bediening leidt tot een opwekking, na zijn bezoek aan de conferentie in Brighton (1875), waar ook Abraham Kuyper aanwezig is. De opwekking in Oosterwolde en Oldebroek mondt na het vertrek van Bähler uit in de stichting van de vereniging 'Luctor et emergo', die functioneert als een vrije evangelische gemeente. Na Oosterwolde dient vader Bähler de hervormde gemeenten Lage Zwaluwe en Groningen tot zijn emeritaat in 1907.

Louis Adriën studeert van 1886-1890 in Groningen, waar hij in 1893 promoveert. Daarna wordt hij predikant op Schiermonnikoog (1895), in Oosterwolde in Friesland (1902) en in Aduard (1909), waar hij na twee jaar zijn ambt neerlegt. Hij vestigt zich in Paterswolde op het landgoed Lemferdinge, waar hij zijn pacifisme blijft uitdragen en de iriscopie beoefent.

De relatie met zijn orthodox-evangelische vader is gespannen. $\mathrm{Al}$ in zijn studietijd ontwikkelt Louis vrijzinnige sympathieën. ${ }^{8}$ Zijn vader weigert hem te bevestigen in het ambt van predikant. Vlak voor zijn bevestiging in november 1895 schrijft hij aan zijn vader: 'Ik geloof in Jezus als de heerlijkste openbaring van den "Zone Gods" die in ieder mens aanwezig is. [...] U hebt mij herhaaldelijk met woord en pen groot onrecht en groot verdriet aangedaan en het spijt mij innig dat onze wegen zóó uiteenloopen!'9

\section{Het 'Christelijke' Barbarendom (1903)}

Bählers sympathie voor het boeddhisme dateert al van het begin van zijn studietijd. ${ }^{10}$ Deze sympathie blijkt ook uit de stellingen bij zijn proefschrift. 'Bij

7 B. Moorrees, Om de erve der vaderen: Een verzameling van ten tijde der afscheiding uitgegeven geschriften van Bernardus Moorrees, in leven hervormd predikant van Wijk bij Heusden, Wijk en Aalburg 1996, 255-264.

8 E.W.R. Alberts, 'Dr. Louis A. Bähler: Een beknopte bibliografie met daarbij opgenomen een korte biografie', Groningen 1983, 4. Al in 1885 schrijft hij dat Jezus niets meer is geweest dan een gewoon mens. Koops, 'Man van geestdrift', $8 \mathrm{n} 14$.

9 Koops, 'Man van geestdrift', 9-10. Eerdere conflicten hebben te maken met zijn studietempo en een gespannen verhouding met zijn stiefmoeder, die Louis ervan verdenkt dat zij zijn vader tegen hem opstookt. Koops, 'Man van geestdrift', 8.

10 Hij schrijft zelf later dat zijn genegenheid voor het boeddhisme dateert 'van het jaar 1886, toen ik er voor 't eerst nader kennis mee maakte'. L.A. Bähler, Oordeelt mede! De officiële bescheiden in de jongste kerkelijke moeilijkheden, Groningen 1905, 14. 
een goede opleiding van een Christen-Theoloog mag het aan eenige studie van het Boeddhisme tegenwoordig niet ontbreken.'11 Op Schiermonnikoog komt deze sympathie duidelijker naar voren, zoals blijkt uit twee preken die hij houdt over de thema's reïncarnatie en karma. Voor de reïncarnatie geeft hij drie theologische argumenten: Gods rechtvaardigheid - omdat het gedane onrecht wordt opgeheven - Gods liefde - omdat God als Vader ons de kans geeft ons zondige leven over te doen. 'Allermeest echter drijft het geloof in Gods heiligheid mij tot het geloof aan de reïncarnatie. O zeker tot God zijn alle dingen. Maar alle dingen zijn nog zoo onheilig, zoo onrein, zoo onvolmaakt.'12

Het gedichtje in zijn exemplaar van Teellincks Vruchtbaarmakende wijnstok verwijst naar de tuchtprocedure vanwege zijn vertaling uit het Duits van het traktaat Het 'Christelijke' Barbarendom in Europa: Boeddhistische Zending. ${ }^{13}$ In het voorwoord schrijft Bähler, inmiddels predikant in het Friese Oosterwolde, dat 'onze Christelijke wereldbeschouwing waar zij mis is, door de Boeddhistische verbeterd en waar zij onvolledig is, door de Boeddhistische aangevuld kan worden'. ${ }^{14}$ Het gaat hierbij vooral om de ethische consequenties van het boeddhisme, zoals de geweldloosheid en het respect voor het dierlijke leven, die Bähler middels dit geschrift aan het barbaarse christendom ten voorbeeld stelt. Dat doet hij vanuit de gedachte dat de Christus zich zowel in de Boeddha als in Jezus van Nazareth openbaart, al is die laatste openbaring wel zuiverder. Terloops schrijft Bähler ook nog nooit iets voor de zending geofferd te hebben, omdat de zending aan de cultuurvolken in Azië overbodig is en omdat echte christelijke zending onverenigbaar is met kolonialisme.

Bähler maakt onderscheid tussen het boeddhisme als volksreligie en de ware verlichten. 'Vergelijkenderwijs zijn er Christenen die wel de leer van den

11 Stelling 13. De volgende stelling luidt 'XIV. Invloed van het Boeddhisme op het ontstaan van het Christendom kan niet aangetoond worden.' Stelling bij het proefschrift Louis Adriën Bähler, De Messiaanse heilsverwachting en het Israëlitisch Koningschap, Groningen 1893.

12 Louis Adriën Bähler, Reïncarnatie en karma: Twee preeken, Oosterwolde 1903, 21. De preken zijn pas in zijn periode in Oosterwolde in druk verschenen.

13 Anoniem, Buddhistische Mission: Das 'christliche' Barbarentum in Europa, Leipzig z.j.. Vertaald als L.A. Bähler (vert.), Het 'Christelijke' Barbarendom in Europa: Boeddhistische Zending (Blaricum: Vrede, 1903). Het Duitse werk heeft als ondertitel 'Aufruf an alle Erleuchteten und wahren Jünger des erhabenen Buddha, die noch im tiefen Abgrunde religiöser Unwissenheit versunkenen Barbaren und Heiden des Westens auf den Weg der Erlösung zu führen/von einem Lama. Mit einer Vorrede und Anmerkungen vom Verfasser der 'Lotosblüten'.

14 Bähler, 'Voorwoord van den vertaler' in: Het 'Christelijke’ Barbarendom, 7-10, 9. 
historischen Christus aannemen, doch in wie de mystieke Christus nog niet werd geboren. Deze wedergeborenen alleen zijn ware Christenen. ${ }^{15} \mathrm{Zij}$ zouden zich volgens hem niet zo opwinden over de publicatie van een boeddhistisch missionair traktaatje, omdat zij daarin dezelfde heerlijke heilswaarheden ontdekken, waarin hun eigen ziel zich verheugt.

De veronderstelling dat deze oproep aan 'christelijke barbaren' echt door een Tibetaanse monnik was geschreven, berust op een vergissing; het gaat waarschijnlijk om een werk uit de kring van Duitse theosofen, mogelijk van de uitgever Franz Hartmann (1838-1912), de redacteur van het theosofische blad Lotosblüten. Het lijkt ook onwaarschijnlijk dat een monnik uit Tibet zou kunnen schrijven over zeppelins als 'met gas gevulde kogels' waarmee de Europeanen door de lucht vliegen. ${ }^{16}$ Bähler erkent later dat hij beter had kunnen schrijven: 'Het heet oorspronkelijk geschreven te zijn door een Boeddhistischen priester uit Tibet.'17

De publicatie vormt de aanleiding voor de kerkenraad van Amsterdam om een adres tegen Bähler naar de synode te sturen. De synode verwijst de zaak door naar de classis Heerenveen, waartoe de gemeente Oosterwolde behoort. De classis oordeelt dat Bähler zijn uitspraak terug moet nemen en schuld moet belijden. Hij weigert echter, omdat hij vindt dat hij niet in strijd heeft gehandeld met de geloften die hij gedaan heeft bij zijn toelating tot de evangeliebediening. Daarop oordelen de classis en het provinciaal kerkbestuur van Friesland dat Bähler 'schuldig is aan openbaren strijd met den geest en de beginselen van de belijdenis der Hervormde Kerk' en schorst hem voor onbepaalde tijd. ${ }^{18}$

Bähler gaat in beroep en zo komt de zaak weer terug bij een commissie die vanuit de synode is samengesteld, de synodus contracta. ${ }^{19}$ Als hij door die

15 Bähler, 'Voorwoord', 8-9.

16 Bähler (vert.), Het 'Christelijke' Barbarendom in Europa, 23.

17 Bähler, Oordeelt mede!, 5. Vergelijk W.B. Drees, Over Wijsbegeerte van de godsdienst en haar object: Twee formules, Leiden 2002, 24-25 n5.

18 Handelingen van de Buitengewone Vergadering en van de 90ste Gewone Vergadering van de Algemeene Synode der Nederlandsche Hervormde Kerk, ten Jare 1905, Den Haag 1905, 712.

19 Derk Jansen, 'Een stofopjagend gezel': Louis Adriën Bähler: Het 'christelijke' barbarendom in Europa (1903)', in: F.G.M. Broeyer, D.Th. Kuiper (red.), Is 't waar of niet? Ophefmakende publicaties uit de 'lange' negentiende eeuw [Jaarboek voor de geschiedenis van het Nederlands Protestantisme na 1800, 13], Zoetermeer 2005, 285-304, 293-296. Vergelijk over de kwestie Bähler ook nog Marcel Poorthuis, Theo Salemink, en Marga Haas, Lotus in de Lage Landen: De geschiedenis van het boeddhisme in Nederland, beeldvorming van 1840 tot heden, Almere 2009), 170-181. 
commissie gehoord wordt, zegt Bähler dat de classis ten onrechte vindt dat hij Boeddha boven Jezus stelt. Het boeddhisme ziet hij als een openbaring van Christus, het Licht der wereld, aan de Indische mensheid, zonder Boeddha aan Christus gelijk te stellen, laat staan boven Hem te verheffen. Bähler vertelt dat hij zich jarenlang heeft bewogen in socialistische, materialistische en atheistische kringen. 'Daar heerscht een vreeselijk vooroordeel tegen Christendom en godsdienst. Hij hoopt dat velen, zij het dan langs een omweg, ook door kennisneming van het Boeddhisme, zullen worden teruggeleid tot het Christendom. En dat is hem ook gebleken.'20 Met zijn kritiek op de zending heeft hij 'het oog op de Christelijke zending, zooals zij als werktuig der koloniale politiek gedreven wordt, niet b.v. op eene zending zooals die geschiedt van de zijde der Hernhutters. ${ }^{21}$ Uiteindelijk stelt de synodale commissie hem in het gelijk en berispt zij het provinciaal kerkbestuur vanwege de onrechtmatige schorsing.

\section{De 'kwestie Bähler' en de synodale machteloosheid}

Een storm van verontwaardiging steekt op, vooral in orthodox-gereformeerde kring. De commentator in De Heraut, het weekblad van de Gereformeerde Kerken in Nederland, schrijft: 'Al was deze beslissing te voorzien, ze blijft des niettegenstaande een gruwel in de oogen des Heeren en toont opnieuw, hoe diep het bederf in de Hervormde Kerk ingedrongen is. ${ }^{22}$

De kwestie Bähler zorgt ook voor een mobilisatie van de orthodoxie in de Nederlandse Hervormde Kerk tegen de synode. Zo ontstaat in 1906 de 'Gereformeerden Bond tot vrijmaking der Kerken'. Het 'Manifest' waarmee het bestuur de eerste openbare vergadering op woensdag 18 april aankondigt, opent met de woorden: 'De procedure "Bahler" heeft bij vernieuwing de aandacht gevestigd op den diep treurigen, maar ook diep zondigen toestand, waarin onze Kerk verkeert'. ${ }^{23}$ Het gaat daarbij om de procedure die de fnuikende invloed van de synodale structuur op de leertucht aan het licht brengt.

Everardus Egidius Gewin (1843-1909) spreekt bij de oprichtingsvergadering van de Gereformeerde Bond over Bähler als 'een predikant die Boeddha durfde stellen boven Jezus Christus' en zijn collega dominee Maarten van

20 Handelingen van de 90ste Gewone Vergadering van de Synode, 718.

21 Handelingen van de 90ste Gewone Vergadering van de Synode, 709.

22 'Te voorzien' De Heraut, 17 september 1905.

23 De tekst van het manifest werd gepubliceerd in het Gereformeerd Weekblad, 17 februari 1906 en is onder andere opnieuw gepubliceerd in Gedenkboek Gereformeerde Bond tot verbreiding en verdediging van de waarheid in de Nederl. Hervormde (gereformeerde) Kerk: 1906-1931, Veenendaal 1931, 109-110 en in De waarheidsvriend, 23 april 1981. 
Grieken (1875-1949) noemt hem 'een man, die den heiden Boeddha naast, ja in vele dingen boven Christus verheerlijkt en aanprijst. ${ }^{24}$ Iets wat Bähler zelf in de procedure uitdrukkelijk had ontkend. Het beeld van Bähler als hypocriete cryptoboeddhist wordt in De waarheidsvriend, het officiële orgaan van de Gereformeerde Bond, vaak bevestigd, zoals in een citaat uit 1933:

Maar toen die dappere Boeddhist een verklaring gaf 'dat hij zich niet bewust was, zijn beloften te hebben geschonden', toen trok men hem niet aan de ooren, opdat hij ook nog iets anders zou leeren zeggen - maar de Synode trad eerbiedig terug voor deze persoonlijke, heilige 'overtuiging' van ds. Bähler. ${ }^{25}$

In de historiografie is de vrijzinnigheid van Bähler vaak als oorzaak voor de oprichting van de Gereformeerde Bond gepresenteerd. In de meest recente herdenkingsbundel wordt die beeldvorming terecht gecorrigeerd. 'De kwestieBähler diende echter vooral als illustratie van de door de synode toegestane leervrijheid.'26 Misschien is het nog iets nauwkeuriger om te zeggen dat de kwestie vooral dient ter illustratie van de machteloosheid van de synodale organisatie. De redacteur van De waarheidsvriend schrijft in 1914 dat het kwaad schuilt in het feit dat de synodale organisatie heterogene elementen tot kerkelijke samenleving dwingt. 'De Bähler-geschiedenis is niet anders dan het openbar-

24 Gedenkboek Gereformeerde Bond 1906-1931, 115, 134. Dat Van Grieken het werk niet gelezen heeft, blijkt bijvoorbeeld als hij in 1908 stelt dat het ging om 'een boekje van Boeddhistische zendelingen, die naar het Christelijk Europa waren overgekomen.' M. van Grieken, De Ned. Herv. Kerk in haar tegenwoordigen toestand, Utrecht 1908, 18. De beschuldiging wordt vaak herhaald: 'De Bond is geboren uit de kwestie-Dr. Bähler, Herv. Pred. in Friesland, die Buddha boven Christus en diens leer boven de leer van Christus stelde', De waarheidsvriend, 8 maart 1912. 'Toen in 1905 de bekende kwestie-Bähler zich afspeelde in het midden van onze Herv. Kerk en ieder verbijsterd stond, dat zoo'n Buddhist in z'n ambt gehandhaafd werd', De waarheidsvriend, 28 november 1913.

25 'Kerkelijke rondschouw', De waarheidsvriend, 25 mei 1933.

26 John Exalto en Fred van Lieburg, 'Inleiding: Eene macht te vormen van beteekenis', in John Exalto en Fred van Lieburg, Bonders in opmars: Hervormd-gereformeerden 1890-1960, Apeldoorn 2015, 9-25, 10. Vergelijk de opmerking van Mirjam Hofman: 'Voor bonders van het eerste uur verwees de kwestie Bähler voornamelijk naar een algemeen probleem dat men ter hand wilde nemen.' Mirjam Hofman, 'Geef dat we tot in 't nageslacht Calvijn's begins'len eeren: De hervormd-gereformeerde omgang met het verleden in de periode 1906-1956' in Exalto en Van Lieburg, Bonders in opmars, 339-370, 345. Beide bijdragen aan de bundel verwijzen voor die relativering naar F.R.J. Knetsch, 'Een kerk in gisting: hervormde stemmen 1892-1907', Documentatieblad voor de Nederlandse kerkgeschiedenis na 180036 (1992) 67-87, 73-74. 
sten van het gezwel, waarvan het bestaan voor niemand verborgen kon zijn. ${ }^{27}$

Vijfentwintig jaar na dato roept De waarheidsvriend in herinnering dat Bähler met een verklaring kwam dat hij niet had bedoeld om het boeddhisme boven het christendom te stellen. Daarmee is de zaak in formele zin beslecht, maar het onwaarachtig optreden van Bähler leidt tot het gevoelen 'over de heele breedte van de orthodoxie, dat het zóó toch in de Kerk van Christus niet gaan mag [...] en dat heeft ook tegen-actie in 't leven geroepen, méér dan te voren, zoodat sinds de kracht van de orthodoxie meer is geconcentreerd en 't kerkelijk vraagstuk aller aandacht heeft. ${ }^{28}$

De 'Gereformeerden Bond tot vrijmaking der Kerken' ontstaat niet als reactie op de vrijzinnigheid van Bähler, maar op het terugdraaien van zijn schorsing door de synode. De 'kwestie Bähler' wordt de aanjager om te pleiten voor het opheffen van de synodale organisatie en de vrijmaking van de kerken, een pleidooi waar de Gereformeerde Bond als het erop aankomt toch telkens voor terugschrikt. ${ }^{29}$

\section{Christen-anarchisten}

Louis Adriën Bähler neemt onder de vrijzinnige hervormden een extreme positie in. ${ }^{30}$ Met andere modernen heeft hij de relativering van de historiciteit van de Evangeliën en de nadruk op de ethiek van de Bergrede gemeen. Hij is

27 'Een Bondspraatje', De waarheidsvriend, 17 april 1914.

28 'Kerkelijke rondschouw', De waarheidsvriend, 17 mei 1929.

29 Zie hiervoor Henk van den Belt, 'De kerk slopen of renoveren? De vrijmaking van de plaatselijke kerken bij de oprichting (1906) en de doorstart (1909) van de Gereformeerde Bond', in Theologia Reformata 62/1 (2019), 7-26. Dat de naam van de Bond in 1909 wijzigt in 'Gereformeerde Bond tot verbreiding en verdediging van de Waarheid in de Nederlandsche Hervormde (Gereformeerde) Kerk' heeft maar een zeer betrekkelijke betekenis.

30 In vrijzinnige kring leeft de vrees dat hij het orthodoxe vooroordeel bevestigt dat modernen geen echte christenen zijn. Zie voor de kritiek van de remonstrantse hoogleraar Hermanus IJsbrand Groenewegen (1862-1930) in het blad van de Nederlandsche Protestantenbond De Hervorming, Jansen, 'Een stofopjagend gezel', 290. De Hervorming citeert ook de orthodoxe Andries Willem Bronsveld (1839-1924) dat 'menig moderne heimelijk niet ongaarne van zulk een wonderlijk gezel, die hun zaak compromitteert, zou worden verlost.' Tom-Eric Krijger, A Second Reformation? Liberal Protestantism in Dutch Religious, Social and Political Life, 1870-1940, Groningen 2017, 210 n67. Zelf keert Bähler zich soms ook expliciet tegen modernen die hij niet radicaal genoeg vindt en verwijt bijvoorbeeld Johannes Henricus Scholten (1811-1885), één van de grondleggers van de moderne theologie in Nederland, dat hij heult met het militarisme. L.A. Bähler, Twee levensbeginselen: Liefde-zelfzucht, geloofsvrijheid-staatsdwang, dienstweigering-krijgsdienst, vrede-oorlog, geluk-ellende, Oosterwolde 1903, 23. 
geen representatieve vertegenwoordiger van het modernisme, maar wel een exponent van bepaalde tendensen in de vrijzinnigheid, zoals de relativering van de historische Jezus en de nadruk op de morele boodschap van het evangelie. De consequenties daarvan werkt hij samen met andere 'christenanarchisten' op radicale wijze uit, geïnspireerd door de Russische schrijven Leo Tolstoj (1828-1910). ${ }^{31}$ Zij roepen op tot volstrekte geweldloosheid, ook als het gaat om zelfverdediging, en streven naar bescherming van het leven, ook van het dierlijke leven, bestrijden alcoholisme, vivisectie en propageren een rein leven zonder genotsmiddelen en geweld en zien seksualiteit uitsluitend als iets voor de voortplanting. ${ }^{32}$

Bähler geniet als prediker populariteit in de gemeenten die hij dient; '... er gaat een zachte vriendelijkheid van dezen man met de lange baard uit, eenvoudig gekleed en eenvoudig in zijn optreden: - de zachtheid en eenvoudigheid van den vegetariër en den geheelonthouder, de zachtheid van den idealist.' ${ }^{33}$

Zijn voorliefde voor de prekenbundel van Teellinck staat niet op zichzelf. Zijn uitgave van een kleine selectie uit De vruchtbaar makende wijnstok Christus (1908) in de serie 'Geschriften over het ingekeerde leven' betreft een pamflet van 39 pagina's met een hertaling van enkele exegetische passages. Er is geen verantwoording of inleiding en in de uitgave motiveert hij nergens zijn keuze voor deze tekst. De andere deeltjes in de serie hebben een vergelijkbaar karakter. In het eerste deel, een uitgave van Johannes Tennhards Onderwijzing door het Inwendige Woord Gods, vermeldt Bähler dat 'alle geschriften der zuivere mystiek [...] de uitspraken bevatten van het Woord,

31 De belangrijkste vertegenwoordigers van dit 'christen-anarchisme' zijn, naast Bähler, Felix Ortt (1866-1959) en Lodewijk van Mierop (1870-1930), beiden betrokken bij de anarchistische kolonie in Blaricum en bij de uitgave van het antimilitaristische blad Vrede. Zij organiseren zich vooral in de Vereniging Internationale Broederschap waarvan Vrede het officiële orgaan is. Zie André de Raaij, 'Internationale Broederschap: Christen-anarchisme rond de eeuwwisseling' in De AS: Anarchistisch tijdschrift 19 [nummer 95], 6-12, zie www.tijdschrift-de-as.nl, geraadpleegd op 24 juni 2019. De kolonie eindigde tijdens de spoorwegstaking van 1903 toen inwoners van Blaricum de kolonie belegerden; zie Maria Boersen, De kolonie van de Internationale Broederschap te Blaricum (Blaricum: Historische Kring Blaricum, 1987).

32 De christenanarchisten organiseren zich ook in diverse andere verenigingen, zoals de Nederlandsche Vegetariërsbond (NVB), de Nederlandsche Bond tot Bestrijding der Vivisectie (NBBV) en de Rein-Leven Beweging (RLB). Over het netwerk zie Dennis de Lange, Tolstojanen in Nederland: Het Tolstojanisme als sociale beweging (Utrecht: Kelderuitgeverij, 2010).

33 Anoniem, 'Karakterschets: Ds. Louis A. Bähler' in De Hollandsche revue 10/9 (1905), 597 611, 610. Vergelijk voor zijn populariteit in Oosterwolde, Koops, 'Man van geestdrift', 20. 
dat van eeuwigheid af bij God zijnde, toch tevens in o $\mathrm{n} \mathrm{s}$ zijn tent heeft opgeslagen. ${ }^{34}$ Het is de bedoeling geschriften uit verschillende tijden en afkomstig van verschillende volken in de serie te publiceren. Uiteindelijk zijn het er maar drie geworden. ${ }^{35}$

In de periode waarin Bähler zijn selectie uit Teellincks werk publiceert, heeft hij een bredere belangstelling voor de christelijke mystiek. In het blad Vrede publiceert hij fragmenten van Thomas a Kempis' De imitatione Christi. Daarnaast is hij lid van de op de mystiek georiënteerde bijbelstudiekring 'Gemeenschap van Johannes den Evangelist'. ${ }^{36}$ Gevraagd waarom hij zich niet inlaat met de politiek of met sociale vraagstukken, antwoordt Bähler: 'Ik ben geen materialist. [...] Ik wil de menschen dus behulpzaam zijn om eerst het koninkrijk Gods te vinden, de stoffelijke zaken volgen dan wel vanzelf.' ${ }^{37}$

\section{Johanneïsch christendom}

De keuze voor een bloemlezing uit Teellincks werk over Johannes 15 houdt wellicht verband met Bählers voorliefde voor het vierde Evangelie. Hij ontwikkelt als predikant op Schiermonnikoog een esoterische visie op Christus

34 L.A. Bähler, 'Inleiding' in J. Tennhard, Onderwijzing door het inwendige woord Gods: In vragen en antwoorden opgesteld in den jare 1711 [Geschriften over het ingekeerde leven, 1], (Den Haag: Vrede, [1906]), 3.

35 In het tweede deeltje biedt Bähler een hertaling van de Nederlandse vertaling door Gerrit Tersteegen van een mystiek werk. Johannes Bernières de Louvigni, Over de tegenwoordigheid Gods en de overgave aan zijne voorzienigheid. naar het oorspronkelijk Fransch samengevat en in het Duitsch overgezet door G. Tersteegen in de jaren 1726 en 1727 [Geschriften over het ingekeerde leven, 2], (Den Haag: Vrede, [1907]). In het archief van de Rijksuniversiteit Groningen bevindt zich een verslag van de bestuursvergadering van de stichting 'Het ingekeerde Leven' op 7 juni 1907. Lodewijk van Mierop is voorzitter en Bähler zelf 'schrijver'. Samen met beide andere bestuursleden besluiten zij de uitgave van de serie waarin nu twee deeltjes verschenen zijn over te nemen. De stichting is geen lang leven beschoren; het verslag eindigt met het afschrift van een brief (18 januari 1911) van Van Mierop met het voorstel er maar mee te stoppen en een half overgeschreven antwoord van Bähler.

36 André de Raaij, 'Mystiek of actie? Christenanarchistische dilemma's na 1903', in Vijfde Jaarboek Anarchisme [dubbelnummer van De AS: Anarchistisch tijdschrift, jaargang 26, nummer 122-123], (Moerkapelle: Stichting De AS, 1998), 53-61, 60, zie www.tijdschriftde-as.nl, geraadpleegd op 24 juni 2019. In het archief van Bähler in de bibliotheek van de Rijksuniversiteit Groningen bevinden zich verschillende stukken die op de 'Gemeenschap van Johannes den Evangelist' betrekking hebben. Vergelijk ook Poorthuis, Salemink, en Haas, Lotus in de Lage Landen, 181.

37 Anoniem, 'Karakterschets', 611. 
en spreekt met voorkeur over het 'Johanneïsch christendom'. ${ }^{38}$ Voor dit christendom is het weggelegd, om het algemene godsbegrip te individualiseren, door het meteen ook te verinnerlijken. 'God werd hiermee weer de eigen persoonlijke God van een iegelijk onzer. Evenwel niet als een eigen persoonlijke God buiten ons, maar als een eigen persoonlijke God in ons. ${ }^{39}$

Cruciaal voor zijn ontwikkeling is een preek, gehouden in oktober 1896, over de tekst 'Niemand komt tot de Vader dan door Mij' (Joh. 14:6b). ${ }^{40}$ Het vierde Evangelie is niet alleen voor orthodoxen geschreven, nee 'het diepzinnige, hoogverhevene, innigvrome Johannesevangelie zij ook lees- en leerboek van den moderne. ${ }^{41}$ De Logos uit de proloog van het Johannesevangelie legt Bähler uit als 'de Rede' waardoor of door wie Gods scheppingsplan tot in detail is uitgewerkt en door wie het ideële model tot materiële vorm is geboetseerd. De Rede is vlees geworden en is door middel van ons mensen bezig Gods denkbeelden te openbaren.

God de Vader is de absolute God en de Zoon is God in openbaring, al zijn Vader en Zoon gebrekkige benamingen. De Zoon is God zoals Hij in elk mens aanwezig is die in de wereld komt. In Jezus van Nazareth is een mens opgestaan, die reiner en groter is dan alle anderen. In Jezus heeft de Zoon zich het zuiverst geopenbaard. ${ }^{42}$ De bruiloft te Kana en de opwekking van Lazarus zijn een soort gelijkenissen bij de uitspraken 'Ik ben de ware wijnstok' en 'Ik ben de opstanding en het leven.' Als de verloren zoon uit de gelijkenis tot zichzelf komt, dan is dat 'zelf' Gods Zoon in de verloren zoon. Als hij tot redelijk inzicht gekomen is, gaat hij de weg van de bekering op. Dat bedoelt Bähler niet rationalistisch maar mystiek en zo wil hij een brug slaan tussen orthodoxie en modernisme: 'De moderne die gelooft in een Inwendigen God en in dezen als den Zoon des Vaders, en de orthodoxe die zijn eigen orthodoxie begrijpt en dus hetzelfde gelooft - zij reiken elkaar de hand en gaan samen.' 43 De Jezusfiguur in het vierde Evangelie is 'een belichaamde verpersoonlijking van 's menschen inwonende Godheid. Daar is Jezus niet de historische tim-

38 Alberts, 'Louis A. Bähler', 4 met een verwijzing Oosthoeks geïllustreerde encyclopedie, $2^{\text {de }}$ druk (Utrecht, 1925) 2:113-114.

39 Bähler, Geestelijke wasdom: Toespraken (Blaricum: De Waelburgh, [1905]), 122.

40 Hij verwijst zelf naar 'het Johanneïsch Christendom [...] waarvan ik [...] sinds eenige jaren een belijder en verkondiger ben (getuige ook mijn preekenhundel "Zelfopenbaring")', Bähler, Oordeelt mede!, 14.

41 Bähler, Zelfopenbaring, $2^{\text {de }}$ druk (Den Haag: Vrede, 1906), 67-68.

42 Bähler, Zelfopenbaring, 79.

43 Bähler, Zelfopenbaring, 82. 
merman van Nazareth, maar het Godskind, de Zoon Gods, in elken mensch.' ${ }^{4}$

Zijn johanneïsche christendom speelt ook bij de kerkelijke procedure tegen Bähler een rol. Zo schrijft hij aan het bestuur van de classis Heerenveen:

Ik geloof in Christus en ben dus Christen. [...] Het is Christus die door middel van den historischen mensch Siddhartha Gautama (de Boeddha, HvdB) zich aan de Indische menschheid heeft geopenbaard. Het is Christus die in Jezus van Nazareth een blik op God den Vader heeft gegeven, waarvan het Johanneïsch evangelie de schoonste getuigenis aflegt. ${ }^{45}$

Tegenover het christendom dat - zoals de titel van de vertaalde brochure aangeeft - tot barbarendom is vervallen en dat wel christelijk heet, maar zedelijk lager staat dan het boeddhisme, staat volgens Bähler, 'een Christendom, dat de openbaring van Christus zuiver heeft ontvangen en zuiver heeft bewaard. Dit laatste, ware, eenige en eeuwige Christendom wordt door slechts eene kleine schare vertegenwoordigd.' 46

Tijdens de procedure roept zijn vader hem verschillende malen in brieven - geschreven in geheimschrift waarbij de Griekse letters steeds Nederlandse letters representeren - op om Boeddha nu eens te laten rusten en te laten zien hoe hoog hij Jezus boven Siddartha stelt, om nog meer misverstanden te voorkomen. 'Dit alleen zou ik zeggen: laat het Johanneïsche evangelie nu eens door $\mathrm{u}$ in al zijn Christus heerlijkheid getoond worden zonder Laotze of Boeddha. In het Johanneïsche vind je toch alles: de hoogste hoogten.' ${ }^{47}$

\section{Roeping in de wijngaard}

Bählers voorliefde voor het Johannesevangelie blijkt al bij de keuze van de tekst voor zijn proefpreek als student: 'Ik ben de Goede Herder' (Joh. 10:1116). Zijn vrijzinnigheid heeft dan nog niet de radicale vorm aangenomen die het op Schiermonnikoog zal krijgen. Hij schrijft in de opdracht over zijn geestelijke strijd, die hij 'religieuze radeloosheid' noemt, en stelt dat hij ondanks alles 'zijn ideaal om eenmaal een goed herder te worden, als eene roeping,

44 Bähler, Zelfopenbaring, 219.

45 Bähler, Oordeelt mede!, 13.

46 Bähler, Oordeelt mede!, 14.

47 In een briefkaart van 8 september 1905, geciteerd door Koops, 'Man van geestdrift', 19. Enkele jaren later is vader Bähler milder en geeft hij aan dat hijzelf ook ruimer is gaan denken, Koops, 'Man van geestdrift', 20. 
eene zending bleef gevoelen.' ${ }^{48}$ Daar spreekt hij nog onbekommerd over Jezus als historische persoon en stelt hij ook dat 'al die verre volken met hun vreemde godsdiensten moeten weten wie die Jezus is; ook zij moeten worden toegebracht.' 49 Wij moeten hun verkondigen dat er vrede is door het bloed van het kruis en hun tonen wat Jezus voor ons is door het werk van de zending. De preek eindigt met een indringende oproep om ons te concentreren op het kruis van Christus, al gaat het daarbij niet om de verzoening, maar om het voorbeeld dat Jezus heeft gesteld: 'O! laten wij voortdurend op zijn kruis het oog gericht houden, opdat wij een leven leiden van geloof en toewijding, van liefde en opoffering.' 50

Bählers voorliefde voor het beeld van de wijnstok en de ranken - het thema van Teellincks prekenbundel - kan verbonden worden aan een diepe religieuze ervaring uit zijn studietijd. Onder de titel 'Mijne roeping: Eene Reisherinnering' vertelt Bähler dat hij in 1891 op een Duitse Rijnboot vaart en besluit om het zogenaamde Niederwalddenkmal bij Rüdesheim te bezoeken. ${ }^{51}$ Dat monument uit 1883 met een metershoog standbeeld van de Germania symboliseert de stichting van het Duitse Rijk na de Frans-Duitse Oorlog. Hij wil weten hoe hij zich als pacifist voelt in de nabijheid van zo'n 'krijgsmonument'. Op weg naar de top ziet hij echter een groot Christusbeeld en daar vlakbij twee mannen aan het werk in een wijngaard.

Wat er op dat oogenblik in mij gaande was, begreep ik niet, maar ik moest nog niet dadelijk weggaan. Het was of er nog iets komen zou, dat mij verplichtte tot wachten. Wat werden mij nu de woorden "wijngaard" en "wijnstok" plotseling duidelijk! [...] "Een zeker mensch plantte een wijngaard..." Waar had ik plotseling dien halven zin vandaan?!52

Bij het zien van het Christusbeeld en de twee werkende mannen, ervaart hij zijn roeping om in Christus' wijngaard te werken. Boven op de heuvel staat de trotse Germania als symbool voor bloedige veldslagen, maar tussen de

48 Bähler, De goede herder (Groningen, 1892), opdracht. De preek is gehouden in Groningen op 2 oktober 1890.

49 Bähler, De goede herder, 13.

50 Bähler, De goede herder, 14.

51 Bähler, "Mijne roeping: Eene Reisherinnering. "Ga, werk in mijn wijngaard." Matth. XXI : 28', in Louis Adrien Bähler, Lodewijk van Mierop en Felix Louis Ortt (red.), Eerste vredebundel (Amersfoort: Drukkerij Vrede, 1904), 252-264.

52 Bähler, 'Mijne roeping', 255. 
wijngaarden spreekt Christus fluisterend tot hem. 'Waar was zijn wijngaard? Ik wist het: zijn wijngaard omvatte de einden der aarde. Welk werk wenschte hij dat er gedaan zou worden in zijn wijngaard? Ik wist het: werken des vredes. ${ }^{53}$

\section{Theologische positie}

Er zitten pantheïstische trekken in de theologie van Bähler. De hele werkelijkheid is doortrokken van Gods aanwezigheid en valt met het goddelijke samen. Mensen en dieren zijn - niet als mensen en dieren, maar 'als God' - onsterfelijk. 'De God van den pantheïst moet Liefde wezen. Want "liefde is wat verbindt". Het $\mathrm{Al}$ verbindt alles en levert dus de volste, de ware, de eenige openbaring van liefde. [...] God is het Al. God is dus Liefde. [...] De Christen kan niet anders dan pantheïst zijn. ${ }^{54}$

Toch zijn er ook elementen in zijn theologie die in strijd zijn met een strikt pantheïsme. Bähler wil niets weten van een onbewuste wereldgeest; God is voor hem een zelfbewust en persoonlijk wezen, een levende God van goedheid, waarheid, schoonheid en liefde. 'God, de Eeuwige Onstoffelijke Oorzaak, hoort en ziet, denkt, gevoelt en heeft lief.' ${ }^{55} \mathrm{Er}$ is wel sprake van een sterke relativering van de historische Jezus; 'Nee, den mensch Jezus ken ik niet, en ik weet niet of ik hem ooit zal kennen, doch den God Jezus ken ik. Van dien God Jezus lees ik in het evangelie van Johannes, van dien God Jezus spreekt ook Thomas van Kempen in zijn onnavolgbare "Imitatio". ${ }^{56}$

Waarschijnlijk is Bähler na zijn definitieve breuk met de kerk en het neerleggen van zijn ambt uiteindelijk wel bij het pantheïsme uitgekomen. In 1935 schrijft hij: 'Ik wensch niet, Boeddhist te zijn. Ik wensch niet, Christen te zijn. Ik wensch, niets te wezen. [...] Er is maar één Heilig Huis en dat is het Universum. Daar ben ik thuis. ${ }^{57}$ In een notieboekje maakt hij later de aantekening: 'Ik ben pantheïst'. ${ }^{58}$

53 Bähler, 'Mijne roeping', 256-257.

54 Bähler, 'Zelfopenbaring', in Bähler, Van Mierop en Ortt, Eerste vrede-bundel, 278-281, 280.

55 Bähler, De levende God: Rede [Voor denkende menschen, serie 2, nummer 1], Baarn 1911, 12.

56 Bähler, Het christendom: Eene positieve beschouwing, Den Haag 1907, 8-9.

57 Bähler, Het Boeddhisme: Een populair-wetenschappelijke uiteenzetting, Groningen 1935. Het citaat staat in 'Kerkelijke rondschouw' De waarheidsvriend, 1 oktober 1936. De schrijver voegt eraan toe 'Het is toch maar goed, dat zoo'n dominé het in de Ned. Hervormde Kerk niet kon uithouden. Heel veel heeft onze Kerk er niet aan verloren.' Vergelijk voor het citaat ook Koops, 'Man van geestdrift', 27.

58 Koops, 'Man van geestdrift', 27. Koops vermeldt niet wanneer Bähler dit precies schrijft. 
Zijn 'Johanneïsche christendom' gaat gepaard met een sterke tegenstelling tussen de God van het Oude en die van het Nieuwe Testament. Johannes leert ons dat de Zoon van God niets met de Joodse Messias gemeen heeft. 59 'De eigenlijke bijbel van het Christendom is ons Nieuwe Testament. [...] Het beginsel van het O.T. is weerwraak. Het beginsel van het N.T. is weerloosheid.' ${ }^{60}$ Jahwe is de oud-Israëlitische krijgsgod. ${ }^{61}$ Het semitisch element in de Europese cultuur moet ten onder gebracht worden. 'Wij zijn geen Semieten, wij zijn ook uit Indië.'62

Bählers boeddhistische sympathieën bepalen sterk de beeldvorming rond zijn persoon en werk. Daarmee zijn de aspecten van het christen-anarchisme, zoals zijn antimilitarisme, zijn strijd tegen alcoholmisbruik en voor de dierenbescherming, in de vergetelheid geraakt. Bähler heeft zelf deze ideeën met het boeddhisme verbonden en steeds benadrukt dat christenen vooral in de ethiek aan boeddhisten een voorbeeld kunnen nemen.

De Boeddhavrees onder de Christenen is epidemisch. Nu - er zijn talloos veel Christenen die terecht vreezen dat zij een Christelijker leven zouden moeten gaan leiden, indien zij Boeddhist werden. [...] Zodraa de Christen-heid Christelijk wordt, heeft het Boeddhisme hier in humanitair opzicht afgedaan.' ${ }^{63}$

Net als bij de orthodox-gereformeerden, vinden we bij Bähler ook de oproep tot zelfonderzoek: 'O, laat het u ernst zijn! Bedenkt dan toch dat er geen zoo verborgen ondeugd is (en die zijn er vele), dat er geen zoo geheime zonde is (en die zijn er vele), of er is Een die alles opmerkt.' ${ }^{64}$ De stem van het geweten is de stem van God. Soms waarschuwt hij scherp tegen oppervlakkigheid en lafheid. In een preek over de enge Poort: 'Wee, wee uwer! die den breeden weg bewandelt. Hoe eraf te komen als ge uw verderf inziet? Eén middel maar is er: terug te gaan, terug! Het enige goedgaan op de slechte weg is teruggaan. Alles den rug toekeeren...' ${ }^{65}$ De preek klinkt heel christocentrisch: 'Ik ben de

59 Bähler, Mijn Jezus: Twaalf preeken, Den Haag 1901, 19.

60 Bähler, Mijn Jezus, 33.

61 Bähler, Mijn Jezus, 94.

62 Bähler, Het boeddhisme in Europa [Kerk en secte, serie 5, nummer 3], Baarn 1911, 42.

63 Bähler, Boeddhisme in Europa, 40-41. Het boeddhisme kan het christendom echter ook leerstellig wel aanvullen, bijvoorbeeld in de leer van de reïncarnatie. Bähler, Boeddhisme in Europa, 42.

64 Bähler, Levende God, 13.

65 Bähler, Geestelijke wasdom, 201. 
deur. Zoo zegt de Jezus van de 4den Evangelist.' Jezus is echter voor Bähler de belichaming van de inwonende godheid die uiteindelijk eenswezens is met de Krishna van de hindoes. Daarom ligt het geheim van de verlossing in de mens zelf: 'Zoek de enge poort binnen de engte van uw eigen aanzijn. Zoek haar binnen u zelven, want in uw Hoogere Zelf zijt gij haar zelve.' ${ }^{6}$

\section{Louis Adriën Bähler als spiegel}

In de theologie van Louis Bähler is er sprake van een relativering van de historische Jezus en van een mystieke spiritualisering van het christelijke geloof. Beide leiden niet alleen tot een marcionitische en antisemitische visie op het Oude Testament, maar ook tot een moralisering van het evangelie, met een sterke nadruk op de ethiek van de Bergrede. Louis Adriën Bähler is niet representatief voor de vrijzinnigheid, maar in zijn excentriciteit als christen-anarchist wel een exponent van de moderne richting.

Bähler krijgt van zijn orthodox-gereformeerde afkomst en opvoeding een voorliefde mee voor de piëtistische vroomheid. Daar liggen waarschijnlijk de wortels voor zijn sympathie voor Teellinck. Hij is er met hem van overtuigd dat in de verbinding met Christus - 'Hij blijft mijn Wijnstok, ik Zijn rank' het geheim van het christelijke leven schuilt. Uit het verhaal van zijn roeping blijkt dat hij een antenne heeft voor 'het innerlijke woord' als de stem van Christus die hem onmiddellijk aanspreekt en in zijn preken klinkt een ernstige oproep tot levensheiliging en zelfonderzoek door. Vanuit zijn spiritualisering van het christelijke geloof ziet hij in andere religies ook openbaringen van Christus en hij ziet het als zijn roeping om aan het verwaterde christendom van zijn dagen een spiegel voor te houden.

Bählers mystiek verbindt hem enerzijds met de piëtistische traditie waar hij uit afkomstig is, maar diezelfde mystiek leidt tot een relativering, niet alleen van de historiciteit, maar ook van de orthodoxe christologie door een verinnerlijking van de Christus als de goddelijke Logos die in potentie in ieder mens schuilt en bij sommigen, zoals bij Buddha en Jezus, op een bijzondere wijze tot uiting komt. Zijn nadruk op de kleine schare van ware christenen met als kenmerk een hoge morele standaard kent een parallel in de piëtistische nadruk op de levensheiliging als kenmerk van de wedergeboorte. In Bähler raakt het vrijzinnige aan het ultra-gereformeerde. ${ }^{67}$

In de relativering van de heilshistorie ligt het grootste verschil tussen hem en Teellinck, zoals een recensent van de brochure schrijft, is er 'een hemels- 
breed verschil tusschen het ingekeerde leven van den Buddhist en de unio mystica van Teellinck's: "Blijft in mij en in u"'. ${ }^{68}$

Bähler heeft een theologische ontwikkeling doorgemaakt van een oprecht zoekende student, via een spiritualisering en moralisering van het evangelie en een relativering van de uniciteit van het christendom tot een pantheïstische visie op het universum. Het zou interessant zijn om hem nog wat nauwkeuriger in de historische context te plaatsen. Een grondig onderzoek naar zijn netwerk - zowel in de kring van christen-anarchisten als in de piëtistisch georiënteerde heiligingsbeweging - zou informatie kunnen opleveren over dwarsverbanden tussen de verschillende richtingen. Er is in ieder geval genoeg archiefmateriaal om over de intrigerende persoon van Bähler een uitvoerige wetenschappelijke biografie te schrijven. ${ }^{69}$

Tijdens de hoorzitting vraagt de synodus contracta aan Bähler of hij blij is met de beroering die zijn zaak in de kerk teweeggebracht had. Hij antwoordt: 'Dat woord is te sterk; maar ik geloof, dat er iets goeds uit zal voortkomen'.70 Met die woorden kunnen de oprichters van de Gereformeerde Bond wel instemmen. De kwestie Bähler maakt zichtbaar dat de synodale organisatie machteloos is. De tolerantie van zijn extreme vrijzinnigheid mobiliseert de orthodoxie tot een beweging tot vrijmaking van de kerken. Daarbij is Bähler ten onrechte als een onoprechte cryptoboeddhist afgeschilderd en daardoor blijft in de historiografie onderbelicht dat er in zijn sympathie voor de mys-

67 Vergelijk hiervoor het bekende artikel van A.A. van Ruler, 'Ultra-Gereformeerd en Vrijzinnig,' in: A.A. van Ruler, Verzameld werk: Christus, de Geest en het heil, deel 4B (Zoetermeer: Boekencentrum, 2011), 721-801, 725. Het artikel is oorspronkelijk gepubliceerd in Wapenveld 21 (1971), 13-52. Knottnerus betoogt dat gebieden in Friesland en Groningen die in de achttiende eeuw centra zijn van oranjegezindheid en bevindelijk geloof tegen het einde van de negentiende eeuw bolwerken van vrijzinnigheid en anarchisme worden. Otto S. Knottnerus, 'Anarchisme als geseculariseerde bevindelijkheid', in Eerste Jaarboek Postdoctoraal Instituut voor de Sociale Wetenschap, Amsterdam 1991, 87-98. Gepubliceerd op https://ottoknot.home.xs4all.nl/werk/

68 De recensie verschijnt in het blad van de Confessionele Vereniging en de recensent kan wel waardering opbrengen voor het praktische christendom van Teellinck, met zijn neiging tot een mystieke en ascetische opvatting van de ernst van het leven. De Gereformeerde Kerk 21 (1908-1909) 22 oktober 1908.

69 Naast archiefstukken die zich bevinden in de universiteitsbibliotheek te Groningen is er ook het zogenaamde Lemferdingearchief van Bähler en zijn vrouw Gesiena Boerma dat is ondergebracht bij het Drents Archief in Assen. Verder is Jan Koops in het bezit van een doos met persoonlijke archiefstukken van Louis Adriën Bähler. Koops, 'Man van geestdrift', 18.

70 Handelingen van de 90ste Gewone Vergadering van de Synode, 716. 
tiek en oproep tot levensheiliging ook een verwantschap is met de orthodoxgereformeerden.

Bählers theologische ontwikkeling houdt ons vandaag ook een spiegel voor. Er is in evangelicale en reformatorische kring een toenemende nadruk op de religieuze ervaring en op de ethische implicaties van het christelijke geloof. Deze nadruk gaat weliswaar niet samen met een spiritualisering van het christelijke geloof, maar wel met een toenemende relativering van de historische heilsfeiten en van de klassieke verzoeningsleer. Religieuze ervaring en discipelschap kunnen echter niet zonder de historiciteit van de verzoening en boodschap van de rechtvaardiging van de goddeloze.

H. van den Belt is hoogleraar systematische theologie aan de Vrije Universiteit Amsterdam en coördinator van het Cornelis Graafland Centrum (Theologisch Instituut van de Gereformeerde Bond). 